\title{
Effect of Dietary Pyrimethamine on Hatchability and a Recommendation on a Procedure to Check Teratogenicity by Hatchability
}

\author{
Minoru Yoshida, Koichi Hirano, Masuo Sueyoshi, Shigeru Ohtsuka and Motoi Oka \\ National Instutite of Animal Health, Kannon-dai, Yatabe, Ibaraki, 305, Japan
}

Standards for evaluation of safety of feed additives are established by Bureau of Animal Industry, Ministry of Agriculture, Forestry and Fisheries, Japan ${ }^{1)}$. Most of feed additives as well as animal drugs are low molecular chemicals, which can be easily taken into the cell. So, in vitro procedures using microorganisms are effective tools to assess their mutagenicity. Intraperitoneal injection of the chemical to pregnant mammals at a certain days after conception is effective to check teratogenicity. In contrast, feedstuffs are natural complexes which can be absorbed only after digestion being broken down into small molecules of nutrients. Therefore, most of the procedures including those mentioned above are unapplicable for testing the presence of an unidentified teratogenic component in the feedstuffs.

To check such a component in feedstuffs, a procedure proposed previously ${ }^{2)}$ testing hatchability of fertile eggs has many advantages. Since most of the deformed chicks cannot break egg shell and died in the shell, teratogenicity can be checked without any special knowledge and experience in teratology. In ontogeny, egg yolk and egg white are only sources of nutrients for the embryo, so normal hatchability means that such eggs are good and safe food. The procedure is simple which is a routine work in commercial hatcheries. Also, it is not necessary to sacrifice the hens.

In the proposed procedure ${ }^{2)}$, incidence of deformed chicks in fertile eggs laid by hens fed the sample is compared with the $99 \%$ upper fiducial limit of the incidence of hens fed normal diets determined previously ${ }^{3)}$. It will be better to prepare positive and negative controls, with and without known teratogenicity, and to compare the response of the hens fed the sample with those fed the controls. The positive control diet should be such that the hens take enough diet and continuously lay fertile eggs. Furthermore, a certain number of both healthy and deformed chicks must be obtained to confirm teratogenicity.

Pyrimethamine is a drug used for the prevention of leucocytozoonosis, of which preventive effect and toxicity to hens were summarized in a review written by АкIвA ${ }^{4)}$. Previous preliminary tests ${ }^{5}$ to use pyrimethamine as a positive control in hatchability test revealed that suitable dietary level of pyrimethamine should be less than $20 \mathrm{ppm}$ to meet various conditions mentioned above.

In this paper, response of laying hens, particularly incidence of deformed chicks are reported feeding them various levels of pyrimethamine upto $20 \mathrm{ppm}$. A procedure of hatchability test to assess teratogenicity of an unidentified substance in feedstuffs is proposed 
based on the responses of the hens.

\section{Materials and Methods}

Materials : Pyrimethamine was a pure drug obtained from Sankyo Kasei Kogyo Co. Ltd. A non-medicated diet for laying hens was used as a basal diet, which was produced by Nihon Haigo-Shiryo Co. Ltd. Experimental diets were prepared by adding 0, 5, 10, and $20 \mathrm{ppm}$ of pyrimethamine to the basal diet.

Hens and rearing: Thirty-four White Leghorn hens of about 6 months of age were reared in 10 cages containing 3 or 4 hens each. To the hens of 3,2,3, and 2 cages, which corresponded to $11,6,11$, and 6 hens, respectively, were fed experimental diets containing $0,5,10$, and 20 ppm of pyrimethamine, respectively, for 7 weeks. Individual body weight was weighed at the beginning and at the end of the experiment and every 2 weeks during the experiment. Feed intake of individual cages was recorded weekly.

At 9 days after the start of the experiment, the hens were inseminated artificially. The eggs were began to collect 2 days after the insemination, and stored at room temperature for 2 weeks. Artificial insemination was repeated at intervals of 4 to 6 days during the experiment. The eggs were set in an incubator to test hatchability. Collection of fertile eggs and the hatchability test on them were repeated 3 times.

Hatchability test: The eggs in the incubator were tested at 5, 12, 18 days after setting the eggs by candling them using a tester made by Showa Furanki Co. Ltd. At full 22 days after setting the eggs in the incubator, the eggs not hatched at that time were assumed to be late death of the embryos, and cracked to examine the deformity.

Deformed chicks were classified as described prevously ${ }^{3)}$, using the card for examination of deformity prepared in the previous studies ${ }^{3)}$.

Statistical analyses : Body weight gain, feed intake and egg production for 7 weeks of the experimental period were analysed as one-way classification taking the dose of pyrimethamine as a factor and individual cages as replication ${ }^{6}$. Data of 3 hatchability tests were analyzed as randomized block design ${ }^{6)}$, taking the does as a factor and assuming each test as a block. The data were transformed into $\sin ^{-1}\left(\mathrm{p}^{0.5}\right)$ before the analyses of variance ${ }^{6}$. Except fertility, of which significant difference was not observed among the doses of pyrimethamine, linear regression between the doses and the responses was examined ${ }^{6}$.

Difference among the means of early death of the embryos was examined by TukEY's multiple test ${ }^{6)}$.

\section{Results}

Results of 3 hatchability tests are presented in Table 1. No statistically significant difference was observed among the results of 3 tests. All the data of 3 hatchability and the data on egg production are summarized in Table 2. Dietary pyrimethamine up to $20 \mathrm{ppm}$ had no significant influence on feed intake, body weight gain and egg production. Dietary pyrimethamine also had no significant influence on fertility. Pyrimethamine increased the incidence of early death of the embryos. Correlation coefficients between the dose of pyrimethamine and mortality of embryo at 5,12 , and 18 days in the incubator were 0.8312 , 0.8882 , and 0.8995 , respectively. The coefficients were fairly large but not significant 
Table 1. Results of hatchability tests

\begin{tabular}{|c|c|c|c|c|c|c|c|c|}
\hline \multirow{2}{*}{$\begin{array}{r}\text { Pyrimethamine } \\
\text { ppm }\end{array}$} & \multirow{2}{*}{$\begin{array}{l}\text { Eggs } \\
\text { set }\end{array}$} & \multirow{2}{*}{$\begin{array}{r}\text { Fertile } \\
\text { eggs }\end{array}$} & \multicolumn{3}{|c|}{ Early death of embryo } & \multirow{2}{*}{$\begin{array}{l}\text { Late } \\
\text { death }\end{array}$} & \multirow{2}{*}{$\begin{array}{c}\text { Deformed } \\
\text { chicks }\end{array}$} & \multirow{2}{*}{$\begin{array}{r}\text { Hatched } \\
\text { chicks }\end{array}$} \\
\hline & & & 5 days & 12 days & 18 days & & & \\
\hline
\end{tabular}

First test :

$\begin{array}{rrr}0 & 93 & 9 \\ 5 & 65 & 6 \\ 10 & 97 & 86 \\ 20 & 55 & 5\end{array}$

$\begin{array}{ll}90 & 10 \\ 64 & 14 \\ 86 & 16 \\ 52 & 11\end{array}$

$\begin{array}{ll}1 & 2 \\ 0 & 1 \\ 7 & 1 \\ 9 & 2\end{array}$

$\begin{array}{ll}2 & \\ 1 & \\ 1 & \\ 2 & 10\end{array}$

$\begin{array}{rrr}7 & 3 & 70 \\ 4 & 3 & 45 \\ 5 & 5 & 57 \\ 10 & 9 & 20\end{array}$

Second test :

$\begin{array}{rrrrrrrrr}0 & 99 & 90 & 4 & 2 & 0 & 1 & 0 & 83 \\ 5 & 63 & 60 & 0 & 0 & 0 & 3 & 2 & 57 \\ 10 & 101 & 95 & 13 & 7 & 3 & 8 & 7 & 64 \\ 20 & 56 & 54 & 9 & 17 & 4 & 12 & 10 & 12\end{array}$

Third test :

\begin{tabular}{rrrrrrrrr}
0 & 100 & 92 & 7 & 1 & 1 & 1 & 0 & 82 \\
5 & 77 & 74 & 6 & 0 & 0 & 3 & 2 & 65 \\
10 & 100 & 93 & 12 & 5 & 2 & 14 & 8 & 60 \\
20 & 78 & 75 & 7 & 14 & 4 & 13 & 9 & 37 \\
\hline
\end{tabular}

Table 2. Summary of effect of pyrimethamine on egg production and hatchability ${ }^{1,2)}$

\begin{tabular}{|c|c|c|c|c|c|}
\hline & & \multicolumn{4}{|c|}{ Dietary levels of pyrimethamine (ppm) } \\
\hline & & 0 & 5 & 10 & 20 \\
\hline No. of hens & & 11 & 6 & 11 & 6 \\
\hline Final body weight & $\mathrm{kg}$ & 1.65 & 1.65 & 1.58 & 1.63 \\
\hline Body weight gain & $\mathrm{g}$ & 61 & 127 & 97 & 67 \\
\hline Feed intake $\mathrm{g} / \mathrm{hen} /$ & & 104 & 103 & 103 & 96 \\
\hline Egg production & $\%$ & 91.0 & 95.9 & 89.7 & 91.7 \\
\hline No. of eggs set & & 292 & 205 & 298 & 189 \\
\hline Fertility & $\%$ & 93.5 & 96.8 & 92.1 & 95.8 \\
\hline \multicolumn{6}{|c|}{ Early death of embryo } \\
\hline 5 days & $\%$ & $7.5^{\mathrm{a}}$ & $6.5^{\mathrm{a}}$ & $15.0^{\mathrm{b}}$ & $15.4^{\mathrm{b}}$ \\
\hline 12 days & $\%$ & $1.4^{\mathrm{a}}$ & $0.0^{\mathrm{a}}$ & $6.9^{\mathrm{b}}$ & $22.2^{\mathrm{c}}$ \\
\hline 18 days & $\%$ & $0.7^{\mathrm{ab}}$ & $0.2^{\mathrm{a}}$ & $2.1^{\mathrm{ab}}$ & $5.4^{\mathrm{b}}$ \\
\hline \multicolumn{6}{|c|}{ Late death of embryo } \\
\hline 22 days $^{3)}$ & $\%$ & 2.7 & 5.1 & 9.4 & 19.5 \\
\hline Deformed chick $^{4)}$ & $\%$ & 0.4 & 3.5 & 7.2 & 15.8 \\
\hline Hatchability $^{4)}$ & $\%$ & 86.9 & 85.8 & 66.1 & 36.2 \\
\hline
\end{tabular}

1) Mean of transformed data was re-transformed into percentage.

2) Difference between means with different superscript in a row was significant $(\mathrm{p}<0.05)$.

3) Significant linear dose-response relationship was observed $(p<0.01)$.

4) Significant linear dose-response relationship was observed $(p<0.05)$.

statistically, mainly due to smallness of sample size with degrees of freedom of only 2 .

Significant correlationship was observed between the dose of pyrimethamine and the late mortality of embryos, incidence of the deformed chicks, and hatchability as shown in Fig. 1.

In Table 3, the distribution of types of deformity of the chicks are presented. Comparing 


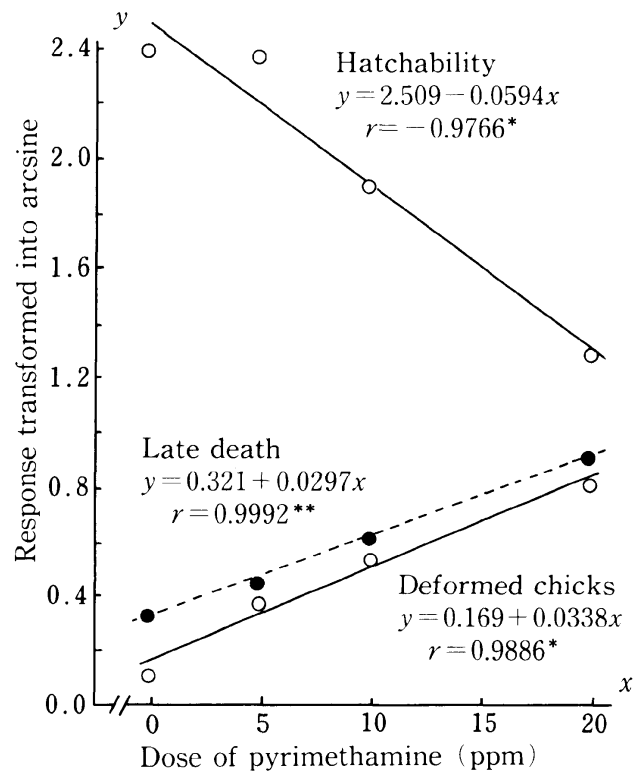

Fig. 1. Dose-response relationship

Table 3. Distribution of deformity of chicks in 3 hatchability tests.

\begin{tabular}{lrrrr}
\hline & & Dietary levels of pyrimethamine (ppm) & \\
& 0 & 5 & 10 & 20 \\
\hline No. of fertile eggs & 272 & 198 & 274 & 181 \\
No. of deformed chicks & 3 & 7 & 20 & 28 \\
Type of deformity : & & & 17 \\
Poor development, dwarf & 1 & 3 & 1 & 19 \\
Cerebral hernia & 0 & 0 & 5 & 5 \\
Short beak & 1 & 1 & 1 & 2 \\
Crossed beak & 0 & 0 & 0 & 1 \\
Umbilical hernia & 0 & 1 & 1 & 11 \\
Frizzled feathers & 0 & 0 & 2 & 1 \\
Skin dropsy & 0 & 1 & 5 & 8 \\
Micromelia & 0 & 0 & 6 & 0 \\
Deformity of joints & 1 & 2 & 0 & \\
Fused duplicity & 0 & 1 & & \\
\hline
\end{tabular}

with the types of the deformity in the control group, in which only 3 types of the deformity were observed sporadically, i. e., the dwarf, short beak, and deformity of joints, frizzled feathers, and micromelia were often observed in the groups administered pyrimethamine.

\section{Discussion}

The linear dose-response relationship as shown in Fig. 1 indicates clearly that dietary pyrimethamine is transferred into the eggs in proportion to the levels of pyrimethamine. The 
pyrimethamine in the eggs affect the embryo in proportion to the concentration of the drug in the egg. Even though the dose of pyrimethamine is as low as $1 \mathrm{ppm}$, a certain amount of the drug remains in the eggs.

Under normal condition feeding no drugs, the most predominant type of deformity is the short beak, of which incidence was $3.0 \%$ of fertile eggs in average ${ }^{3)}$. Incidences of 6 types of deformity, i. e., the dwarf, umbilical hernia, microphthalmia, skin dropsy, crossed beak, and cerebral hernia are high, of which the average incidence was over $1 \%$ being $2.8,2.0,1.4,1.4$, 1.3 , and $1.1 \%$, respectively ${ }^{3)}$. On the other hand, the types frequently observed among the deformed chicks administered pyrimethamine were the micromella, deformity of joints, and frizzled feathers, of which incidences in normal chicks were $0.25,0.54$, and 0.44 , respectively ${ }^{3}$.

The dominant types of deformity induced by pyrimethamine are poor developement of the whole body, beak, legs and feathers.

\section{Recomendation of a procedure of the hatchability test to examine teratogenicity}

Three types of experimetal diets are prepared. Positive and negative control diets are a commercial non-medicated formula feed for laying hens with and without $10 \mathrm{ppm}$ of supplemental pyrimethamine. A test diet is prepared mixing a suitable level of the sample to the non-medicated feed, the level of which should be such that hens fed the diet has good appetite and lay fertile eggs continuously.

The diets are fed to 10 laying hens, and at 10 days after the start of the experiment, the hens are artificially inseminated. Artificial insemination is repeated at intervals of about 5 days. For artificial insemination, it is recommended to keep at least one cock per 10 hens. From 2 days after the first insemination, the eggs are collected and stored at $13^{\circ} \mathrm{C}$ for about 2 weeks.

About 100 eggs per diet are set in an incubator. At 5 and 18 days in the incubator, the eggs are candled. The eggs that do not start growing at the first candling, are judged as infertile. By the second candling, early mortality of the embryos, $x_{1} \%$, is estimated. Eggs not hatched at full 22 days are judged to be late death of the embryos. Number of chicks hatched are counted to get hatchability, $y \%$, against fertile eggs. The incidence of deformed chicks against fertile eggs, $x_{2} \%$, can be calculated by following equation (1),

$$
y=94.36-1.0519 x_{1}-1.5586 x_{2}
$$

It is recommended to conduct 3 hatchability tests continuously. It is recommended to conduct acute toxicity tests with the sample as mentioned previously ${ }^{7)}$ to examine palatabilty and toxicity of the sample before testing teratogenicity by the hatchability procedure

Table 4. Mean and 99\% fiducial upper limit of data of hatchability test.

\begin{tabular}{lcc}
\hline \hline & Mean & $\begin{array}{l}\text { Upper } \\
\text { limit }\end{array}$ \\
\hline Early death of embryo & $\%$ & $\%$ \\
Late death of embryo & 7.8 & 27.4 \\
Incidence of deformed chicks & 1.01 & 25.9 \\
Hatchability & 82.8 & $55.6^{11}$ \\
\hline
\end{tabular}

1) $99 \%$ fiducial lower limit. 
recommended in this paper.

If incidence of the deformed chicks, $x_{2} \%$, be over the $99 \%$ fiducial upper limit shown in Table 4 , which is $8.2 \%$, then it is suspected that something unusual happens. Probably, the sample is teratogenic. The upper limits for early and late mortality of the embryo and the lower limit for hatchability shown in Table 4 are also useful in judgement of teratogenicity of the sample.

\section{Summary}

Teratogenic effect of pyrimethamine at dietary levels of $0,5,10$, and $20 \mathrm{ppm}$ was examined. Fertile eggs obtained by feeding the experimental diets to laying White Leghorn hens, were set in an incubator. Fertility, early and late mortality of the embryos, hatchability and incidence of the deformed chicks were tested.

Pyrimethamine up to $20 \mathrm{ppm}$ had little effect on feed intake, body weight gain, egg production and fertility, but had significant effects on mortality of the embryos, incidence of deformed chicks and hatchability. A linear dose-response relationship was observed between the dose of pyrimethamine and late mortality of the embryos, incidence of deformed chicks, and hatchability.

A procedure of the hatchability test to examine teratogenicity of feedstuffs is recommended

\section{Acknowledgement}

The authors wish to express their deep appreciation to Prof. Hisashi SAKaI, of Nagoya University, for his instrucation on classification of the deformed chicks.

\section{Literature}

1) Bureau of Animal Industry, Ministry of Agriculture, Forestry and Fisheries (1977) Standards for evaluation of feed additives.

2) Yoshida M. (1986) Evaluation of genetic toxicity by hatchability (In Japanese). Chiku-san no Kenkyu $40: 1047 \sim 1050$.

3) Yoshida M., H. Sakai, J. Kitoh, D. Hagano, K. Koba, T. Imamoto, M. Matsushima, H. BANSho, M. IINo, and T. Kato (1981) Comparison of three feeding experiments with hens to check unknown or unexpected factor in a novel feed ingredient. III. Classification and distribution of deformity of chick embryo in hatchability tests. Japan. Poult. Sci., 18:290 $\sim 300$.

4) Aкiвa K. (1970) Leucocytozoonosis of chickens. Nat. Inst. Anim. Hlth. Quart., 10, Suppl. : $131 \sim 147$.

5) Онтsuka M., M. Ока, and M. Yoshida (1987) Adequete dietary level of pyrimethamine as a positive control in a hatchability test. Japan. Poult. Sci., 24:259 262.

6) Yoshida M. (1983) Design of experiments for animal husbandry (In Japanese), Yoken-do, Tokyo.

7) Yoshida M. (1986) Evaluation of acute toxicity by growth of chicks (in Japanese). Chikusan no Kenkyu $40: 601 \sim 605$. 


\title{
孵化に及ぼすピリメタミンの影響，および，餒化試験による
} 催奇形性評価法の提案

\author{
吉田 實・平野孝一・未吉益雄・大塚 茂・岡 基 \\ 農林水産省・家畜衛生試験場, 茨城県筑波郡谷田部町観音台 305
}

飼料中の含量を， $0 ， 5,10$ ，および， 20 ppm の 4 段 階としてピリメタミンの鶏に対する催奇形性を検討した。 約 6 か月齢の白レグ種雌鷄に試験飼料を与えて種卵を採 取し，梛卵器にいれた。試験期間は 7 週間で，その間に 孵化試験を連続して 3 回実施した。

添加量が $20 \mathrm{ppm}$ 以下の条件では, ピリメタミンは, 7 週間の飼料摂取量, 体重増加量, 産卵率, および, 受 精率には殆ど影響せず，それぞれの総平均值は，102 g/ 羽/日，86g，91.9\%，扰よび，94.7\%であった。その 他の捊化成績, すなおち, 発育中止卵発生率, 死でもり 卵発生率, 奇形雊発生率, および, 餒化率に対しては, ピリメタミンは顕著な影響を及ばす。発生率を角变換し
て統計的に検討した結果, ピリメタミン添加量が増加す るにつれて, 死でもり卵発生率と奇形雊発生率は直線的 に増加して有意な正の相関が認められ, また, 孵化率は 直線的に減少して有意な負の相関が認められた。

ピリメタミン給与区の奇形を分類してその発生率を正 常な梛化に抢ける各種の奇形の発生率之比較すると, 体 軀矮少, 短嘴, 関節の異常等の発生率が高く, ピリメタ ミンに特徴的であった。

ピリメタミン $10 \mathrm{ppm}$ 添加, および, ピリメタミン 無添加の飼料を正負の対照とし, 検体添加飼料を与えて 餒化試験を行い 検体の催奇形性を評価する方法が提案 された。

（家离会誌， 24 巻，230～236, 1987） 